\title{
Analisa Pemanfaatan $e$-Puskesmas di Loket Pendaftaran pada Puskesmas Kecamatan Pademangan dengan Metode PIECES
}

\author{
Rendi Muliansah $^{1 *}$, Cahyani Budihartanti ${ }^{2}$ \\ STMIK Nusa Mandiri, Jl. Damai No.8 Warung Jati Barat (Margasatwa), Jakarta Selatan 12740, Indonesia \\ ${ }^{1}$ rendimuliansyah@gmail.com; ${ }^{2}$ cahyani.cbh@nusamandiri.ac.id \\ Corresponding Author*
}

\begin{tabular}{l}
\hline I N F O A R T I C L E \\
\hline Article History: \\
Receive January 1, 2020 \\
Received January 15, 2020 \\
Accepted February 10, 2020 \\
Available Online February 15, 2020 \\
\hline Keywords: \\
e-Puskesmas, \\
Puskesmas, \\
Registration Counter, \\
PIECES
\end{tabular}

\begin{tabular}{l}
\hline Kata Kunci: \\
$e$-Puskesmas, \\
Puskesmas, \\
Loket Pendaftaran, \\
PIECES \\
\hline Korespondensi: \\
Telephone: +6281328436605 \\
e-mail: \\
rendimuliansyah@ gmail.com
\end{tabular}

\section{Pendahuluan}

$e$-Puskesmas merupakan aplikasi multiuser dengan teknologi berbasis web yang memungkinkan untuk digunakan oleh lebih dari satu orang pengguna pada saat yang bersamaan. Aplikasi $e$-Puskesmas sudah web base (bisa dilihat langsung dari komputer yang terconnect ke internet dengan menggunakan browser seperti Internet Explorer, Mozilla Firefox, dan lain sebagainya). Dengan e-Puskesmas pencatatan dan pendataan pasien menjadi sangat mudah karna dilakukan secara elektronik. Layanan aplikasi $e$-Puskesmas juga semakin memudahkan Dinas Kesehatan dalam memonitor data kesehatan masyarakat.

Hal tersebut yang disolusikan terhadap pengguna e-Puskesmas oleh PT. Infokes Indonesia sebagai development e-Puskesmas, termasuk beberapa Puskesmas di DKI Jakarta yang merupakan salah satu base terbesar pengguna $e$-Puskesmas. Di Jakarta Utara sendiri tercatat ada sekitar 3 Puskesmas pengguna layanan $e$-Puskesmas dan salah satunya ada Puskesmas Kecamatan Pademangan.

Dalam penelitian lain mengemukakan bahwa di puskesmas pemancungan terdapat beberapa permasalahan pada sistem informasi seperti terdapat informasi yang tidak akurat yang disebabkan oleh sistem $e$-Puskesmas yang tidak terekap dengan baik [1]. 
Puskesmas Kecamatan Pademangan telah menerapkan e-Puskesmas pada semua layanan pelayanan kesehatan yang tersedia hingga di beberapa Puskesmas Kelurahan dibawah jajarannya seperti : Puskesmas Kelurahan Ancol, Kelurahan Pademangan Barat I, dan Kelurahan Pademangan Barat II. $e$ Puskesmas di terapkan dari layanan Loket Pendaftaran, Poli Layanan kesehatan (Poli Umum, Poli Gigi, Poli Kesehatan Ibu, Poli Kesehatan Anak, Poli Lansia) hingga ke layanan Apotek atau Farmasi. Terutama pada layanan Loket Pendaftaran yang menjadi pintu utama dan titik awal jalannya pelayanan kesehatan dari pasien datang berkunjung hingga pulang kerumah.

Namun pada penerapannya $e$-Puskesmas terdapat kendala yang dapat mempengaruhi jalannya pelayanan kesehatan yang ada Puskesmas Kecamatan Pademangan terutama di Loket Pendaftaran Puskesmas Kecamatan Pademangan, seperti: gangguan jaringan internet dan gangguan bridging dengan Pcare BPJS sehingga pengguna atau petugas terhambat untuk menginput data pelayanan dan juga dapat mengganggu kegiatan pelayanan kesehatan pada setiap Poli.

Dalam penelitian lain mengemukakan bahwa Implementasi $e$-Puskesmas di Puskesmas Kota Padang diharapkan dapat memberikan kontribusi bagi Puskesmas dalam peningkatan efektifitas dan efsisiensi pelayanan kesehatan Hasil observasi aplikasi e-puskesmas belum sesuai dengan kebutuhan petugas puskesmas [2].

Oleh karena itu, maka perlu adanya evaluasi terhadap pemanfaatan e-Puskesmas untuk mengetahui seberapa "PUAS" pengguna khususnya petugas Loket Pendaftaran dalam menggunakan $e$ Puskesmas dalam menjalani tugasnya. Salah satu metode yang bisa digunakan untuk mengevaluasinya adalah dengan menggunakan metode PIECES (Performance, Information, Economic, Control, Effisiency, Service).

\section{Metode Penelitian}

Adapun langkah-langkah penelitian dalam penyusunan skripsi ini sebagai berikut:

1. Identifikasi Masalah

Hal penting yang berhubungan dengan penetapan kerangka kerja atau fondasi untuk penelitian adalah identifikasi masalah yang berhubungan dengan masalah penelitian. Tahap ini dibangun berdasarkan rumusan masalah yang didasari atas latar belakang masalah. Masalah yang ditemukan adalah bagaimana melakukan penilaian pemanfaatan $e$-Puskesmas di Loket Pendaftaran di Puskesmas Kecamatan Padeamangan dengan Metode metode PIECES.

2. Review Informasi

Pengumpulan informasi tentang bagaimana orang lain mendekati masalah yang sama. Literatur penelitian merupakan sumber dari informasi demikian.

3. Pengumpulan Data

Pada tahapan ini, teknik pengumpulan data yang digunakan pada penelitian ini berupa angket atau kuesioner yang didapatkan dari responden dan sumber data dari internet maupun jurnal.

4. Analisis Data

Dalam Analisa Pemanfaatan $e$-Puskesmas di Loket Pendaftaran Puskesmas Kecamatan Pademangan PIECES diperlukan kriteria-kriteria dan bobot untuk melakukan perhitungannya sehingga akan didapatkan alternatif terbaik. Data yang sudah dikumpulkan kemudian diolah dan dianalisis.

5. Penarikan Kesimpulan

Kesimpulan merupakan tahap akhir dari penelitian berdasarkan hasil pengolahan data.

\subsection{Instrumen Penelitian}

Instrumen Penelitian adalah teknik pengumpulan data yang mempunyai langkah penyusunan instrumen penelitian serta mengetahui validitas, realibitas, tingkat kesukaran, daya pembeda, dan pengecoh / distractor suatu data dalam penelitian [3].

Dalam tahap ini, yang digunakan dalam penelitian adalah menggunakan kuesioner. Kuesioner disusun dalam bentuk pertanyaan yang akan dijawab oleh responden. Dengan memberikan kuesioner dan data dari kuesioner tersebut dapat dengan cepat dianalisis. Data terebut meliputi skor penilaian ePuskesmas berdasarkan Performance, Information, Economy, Control, Efficiency and Service.

\subsection{Skala Likert}

Menurut Sugiyono Skala Likert digunakan untuk mengukur sikap, pendapat dan persepsi seseorang atau selelompok orang tentang fenomena sosial [4]. Biasanya disediakan lima pilihan skala dengan format seperti: 

a. Sangat Baik.
d. Cukup Baik
b. Baik.
e. Kurang Baik
c. Memuaskan.

\subsection{Pengumpulan Data}

Metode pengumpulan data adalah teknik atau cara yang dilakukan oleh peneliti untuk mengumpulkan data yang dilakukan untuk memperoleh informasi yang dibutuhkan dalam rangka mencapai tujuan penelitian [5]. Dalam penelitian ini, proses pengumpulan data menggunakan 2 sumber data yaitu data primer dan sekunder. Data Primer merupakan data utama yang digunakan dalam penelitian yang diperoleh melalui observasi, wawancara dan survei [4].

Data primer yang digunakan dalam penelitian ini bersumber dari petugas loket pendaftaran yaitu berupa gambaran tentang $e$-Puskesmas dengan melakukan wawancara terhadap petugas loket pendaftaran, selain itu data tentang tingkat kepuasan petugas loket pendaftaran sebagai pengguna dari $e$-Puskesmas dengan memberikan daftar pernyataan berupa kuesioner.

Data Sekunder adalah data yang diperoleh peneliti secara tidak langsung yang berupa bukti, catatan atau laporan historis. Selain itu data sekunder yang digunakan diperoleh melalui literatur atau studi pustaka seperti buku, jurnal, prosiding dan laman [4]. Selain itu penulis juga menggunakan dokumentasi data yang berkaitan dengan pengolahan data yang dilakukan sistem informasi perpustakaan yang sesuai dengan topik penelitian.

\subsection{Populasi}

Menurut Sugiyono populasi adalah wilayah generalisasi yang terdiri atas obyek/subyek yang mempunyai kualitas dan karakteristik tertentu yang ditetapkan oleh peneliti untuk dipelajari dan kemudian ditarik kesimpulannya [4].

Berdasarkan pengertian tersebut populasi dalam penelitian ini adalah orang yang sering menggunakan $e$-Puskesmas diloket Pendaftaran Puskesmas Kecamatan Pademangan dan penulis mengecilkan populasi hanya berdasarkan Petugas Loket Pendaftaran yang berjumlah 18 orang.

\subsection{Kuesioner (Angket)}

Angket merupakan Pengumpulan data dengan memberikan kuesioner kepada responden kepada pengguna dari sistem informasi tersebut [6]. Kuesioner dapat berupa pertanyaan atau pernyataan tertutup atau terbuka, dapat diberikan kepada responden secara langsung atau dikirim melalui pos atau internet. Jenis kuesioner/angket yang dipakai dalam penelitian ini adalah kuisioner tertutup.

Kuesioner tertutup merupakan Kuesioner yang sudah disediakan jawabannya sehingga responden hanya memilih sesuai dengan jawaban yang ada [7]. Cara ini seringkali lebih efektif kerena responden dapat langsung memberi tanda centang $(\sqrt{ })$ dalam kolom yang disediakan. Responden hanya memilih salah satu dari beberapa alternatif jawaban yang disediakan dalam bentuk skala likert.

Pernyataan atau pertanyaan yang dijawab oleh responden mendapat nilai sesuai dengan alternatif jawaban yang bersangkutan. Kriteria penilaian dari pernyataan tersebut memiliki lima alternatif jawaban, yaitu: Sangat Baik $(\mathrm{SB})=5$, Baik $(B)=4$, Memuaskan $(M)=3$, Cukup Baik $(\mathrm{CB})=2$, Kurang Baik $(\mathrm{KB})=1$.

\subsection{Sampel Penelitian}

Menurut Siregar sample adalah suatu prosedur pengambilan data dimana hanya sebagian populasi saja yang diambil dan dipergunakan untuk menentukan sifat serta ciri yang dikehendaki dari suatu populasi [6].

Rumus untuk menentukan jumlah sample jika ukuran populasinya diketahui dengan pasti, Rumus Slovin dibawah ini dapat digunakan :

$$
n=\frac{N}{1+N(e)^{2}}
$$

Sumber: [8] 


\section{Keterangan:}

$\mathrm{n}=$ Ukuran sampel/jumlah responden

$\mathrm{N}=$ Ukuran populasi

$\mathrm{e}=$ Presentase kelonggaran ketelitian kesalahan pengambilan sampel yang masih bisa ditolerir $(5 \%)$. Maka dengan menentukan besarnya sampel dicari dengan mengunakan rumus:

$$
\begin{aligned}
& \begin{array}{l}
\text { Diketahui }: \mathrm{N}=18 \\
\mathrm{e}=0.05(5 \%)
\end{array} \\
& n=\frac{18}{1+18(0.05)^{2}} \\
& n=\frac{18}{1+18(0.0025)} \\
& n=\frac{18}{1+0.045} \\
& n=\frac{18}{1.045} \\
& n=17.22 \text { dibulatkan menjadi } 17 .
\end{aligned}
$$

Dari hasil perhitungan rumus diatas dapat diperoleh jumlah sampel yang akan diteliti adalah sebesar 17 responden.

\subsection{Metode PIECES}

Metode PIECES adalah "metode analisis sebagai dasar untuk memperoleh pokok-pokok permasalahan yang lebih spesifik. Dalam menganalisis sebuah sistem, biasanya akan dilakukan terhadap beberapa aspek antara lain analisis terhadap kinerja, informasi, ekonomi, pengendalian, efisiensi dan pelayanan [9].

Analisis PIECES ini sangat penting untuk dilakukan sebelum mengembangkan sebuah sistem informasi karena dalam analisis ini biasanya akan ditemukan beberapa masalah utama maupun masalah yang bersifat gejala dari masalah utama. Metode ini menggunakan enam variable evaluasi yaitu :

\section{Performance (kinerja)}

Kinerja merupakan variable pertama dalam metode analisis PIECES. Dimana memiliki peran penting untuk menilai apakah proses atau prosedur yang ada masih mungkin ditingkatkan kinerjanya, dan melihat sejauh mana dan seberapa handalkah suatu sistem informasi dalam berproses untuk menghasilkan tujuan yang diinginkan. Dalam hal ini kinerja diukur dari:

a. Throughput, yaitu jumlah pekerjaan / output / deliverables yang dapat dilakukan/ dihasilkan pada saat tertentu.

b. Response time, yaitu waktu yang dibutuhkan untuk menyelesaikan serangkaian kegiatan untuk menghasilkan output / deliverables tertentu.

2. Information (informasi)

Menilai apakah prosedur yang ada saat ini masih dapat diperbaiki sehingga kualitas informasi yang dihasilkan menjadi semakin baik. Informasi yang disajikan haruslah benar-benar mempunyai nilai yang berguna. Hal ini dapat diukur dengan :

a. Keluaran (outputs): Suatu sistem dalam memproduksi keluaran.

b. Masukan (inputs): Dalam memasukkan suatu data sehingga kemudian diolah untuk menjadi informasi yang berguna.

\section{Economy (ekonomi)}

Menilai apakah prosedur yang ada saat ini masih dapat ditingkatkan manfaatnya (nilai gunanya) atau diturunkan biaya penyelenggaraannya.

4. Control (pengendalian) 
Menilai apakah prosedur yang ada saat ini masih dapat ditingkatkan sehingga kualitas pengendalian menjadi semakin baik, dan kemampuannya untuk mendeteksi kesalahan/ kecurangan menjadi semakin baik pula.

5. Efficiency (efisiensi)

Menilai apakah prosedur yang ada saat ini masih dapat diperbaiki, sehingga tercapai peningkatan efisiensi operasi, dan harus lebih unggul dari pada sistem manual.

6. Service (layanan)

Menilai apakah prosedur yang ada saat ini masih dapat diperbaiki kemampuannya untuk mencapai peningkatan kualitas layanan. Buatlah kualitas layanan yang sangat user friendly untuk end-user (pengguna) sehingga pengguna mendapatkan kualitas layanan yang baik.

\subsection{Analisa Data}

Menurut Ahmadi dan Supriyono menyimpulkan bahwa Analisa adalah penelusuran kesempatan atau stantangan atau sumber. Analisa juga melibatkan pemecahan suatu keseluruhan kedalam bagianbagian untuk mengetahui sifat, fungsi dan saling berhubungan antar bagian tersebut. Analisa sangat diperlukan atau penting karena sifat dari lingkungan sangat dinamis dan berubah dengan cepat [10].

Data yang diperoleh pada penelitian ini ada dua yaitu data kualitatif yaitu data yang berupa informasi dari hasil pendekatan PIECES, Dari data tersebut dilakukan pengolahan analisis data sebagai berikut :

1. Pengolahan data berdasarkan penilaian responden pada kuesioner yang seperti dalam tabel berikut :

Tabel 1. Hubungan Jawaban Skala Likert

\begin{tabular}{lcc}
\hline \multirow{2}{*}{ Alternatif Jawaban } & \multicolumn{2}{c}{ Bobot Nilai } \\
\cline { 2 - 3 } & Positif & Negatif \\
\hline a. SB (Sangat Baik) & 5 & 1 \\
b. B (Baik) & 4 & 2 \\
c. M (Memuaskan) & 3 & 3 \\
d. CB (Cukup Baik) & 2 & 4 \\
e. KB (Kurang Baik) & 1 & 5 \\
\hline
\end{tabular}

2. Uji Validitas, Uji validitas dilakukan untuk menguji sejauh mana ketepatan dan kecermatan suatu alat ukur dalam melakukan fungsinya agar data yang diperoleh bisa relevan atau sesuai dengan tujuan diadakannya pengukuran [8].

Uji Validititas yang dilakukan adalah uji validitas isi. Uji validitas isi dilakukan dengan menggunakan korelasi antara skor tiap pertanyaan dengan skor total dari seluruh pertanyaan menggunakan uji statistika Pearson Product Moment [12].

3. Uji Reliabilitas, Uji reliabilitas adalah proses pengukuran terhadap ketepatan (konsisten) dari suatu instrumen [8]. Dalam pengujian reliabilitas terdapat nilai untuk mengukur tingkat reliabilitas menggunakan instrument PIECES.

Uji reliabilitas pada penelitian ini menggunakan uji statistika Cronbach Alpha Coefficient. Hasil dari uji Cronbach Alpha Coefficient akan menunjukkan apakah kuesioner tersebut sudah reliabel atau belum [12]".

4. Analisis PIECES digunakan untuk mengukur tingkat kepuasan petugas terhadap $e$-Puskesmas kemudian memberikan gambaran bagaimana pengaruh pelayanan yang ada saat ini dan untuk kedepannya menjadi bahan referensi kepada Kepala Puskesmas Kecamatan Pademangan pengambilan keputusan. 


\subsection{Data Kuesioner PIECES}

1. Indikator Performance

Tabel 2. Kuesioner Indikator Performance

\begin{tabular}{|c|c|c|c|c|c|c|}
\hline No & Pertanyaan & SB & B & M & $\mathrm{CB}$ & KB \\
\hline 1. & $\begin{array}{l}\text { Pilihan menu dan navigasi yang tersedia } \\
\text { Memudahkan Anda menggunakan program. }\end{array}$ & & & & & \\
\hline 2. & $\begin{array}{l}\text { Menu dan navigasi yang disediakan dapat dijalankan } \\
\text { dengan mudah dan interaktif. }\end{array}$ & & & & & \\
\hline 3. & $\begin{array}{l}\text { Menu-menu yang tersedia secara instan dapat } \\
\text { memunculkan informasi sesuai dengan yang anda } \\
\text { butuhkan. }\end{array}$ & & & & & \\
\hline 4. & $\begin{array}{l}\text { Tersedia instruksi instruksi pembatalan perintah } \\
\text { dengan mudah manakala diperlukan }\end{array}$ & & & & & \\
\hline
\end{tabular}

2. Indikator Information

Tabel 3. Kuesioner Indikator Information

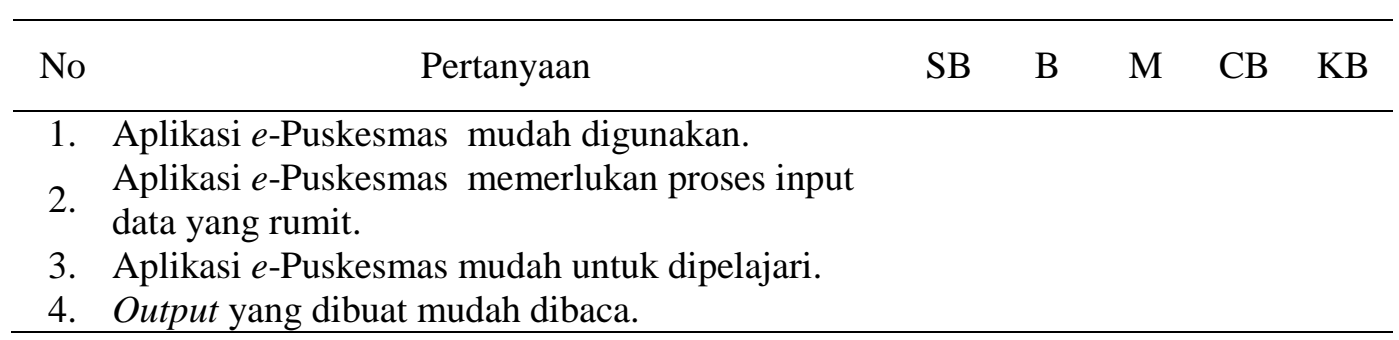

3. Indikator Economy

Tabel 4. Kuesioner Indikator Economy

\begin{tabular}{|c|c|c|c|c|c|}
\hline No & Pertanyaan & SB & B & M & $\mathrm{CB}$ \\
\hline & $\begin{array}{l}\text { Aplikasi } e \text {-Puskesmas mempercepat penyelesaian } \\
\text { pekerjaan. (efisiensi waktu) } \\
\text { Aplikasi } e \text {-Puskesmas memiliki hasil yang } \\
\text { akurat.(efisiensi target) } \\
\text { Aplikasi } e \text {-Puskesmas menghemat biaya } \\
\text { operasional.(efisiensi biaya) } \\
\text { Dengan menggunakan aplikasi } e \text {-Puskesmas, } \\
\text { pekerjaan menjadi lebih mudah diselesaikan. } \\
\text { (efisiensi tenaga dan pikiran) }\end{array}$ & & & & \\
\hline
\end{tabular}




\section{Indikator Control}

Tabel 5. Kuesioner Indikator Control

\begin{tabular}{lllllll}
\hline No & \multicolumn{1}{c}{ Pertanyaan } & SB & B & M & CB & KB \\
\hline 1 & $\begin{array}{l}\text { Aplikasi } e \text {-Puskesmas tidak pernah mengalami } \\
\text { error saat Digunakan }\end{array}$ & & & & & \\
2 & Aplikasi $e$-Puskesmas terbebas dari virus & & & & & \\
3 & Proses pencarian data berlangsung cepat & & & & & \\
& Data yang ada tidak dapat dirubah oleh pengguna \\
4 & selain petugas (keamanan data terjamin) & & & & \\
\hline
\end{tabular}

5. Indikator Effeciency

Tabel 6. Kuesioner Indikator Effeciency

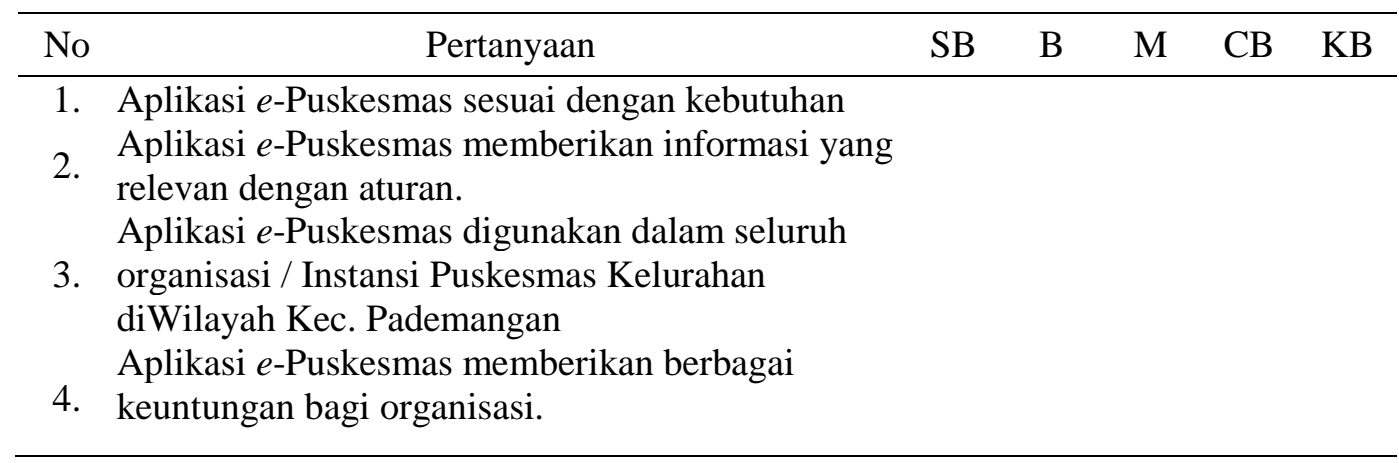

6. Indikator Service

Tabel 7. Kuesioner Indikator Service

\begin{tabular}{|c|c|c|c|c|c|c|}
\hline No & Pertanyan & SB & $\mathrm{B}$ & M & $\mathrm{CB}$ & $\mathrm{KB}$ \\
\hline 1 & $\begin{array}{l}\text { Aplikasi } e \text {-Puskesmas dapat digunakan dengan } \\
\text { mudah. }\end{array}$ & & & & & \\
\hline 2 & $\begin{array}{l}\text { Setiap submenu di menu Pendaftaran dapat diakses } \\
\text { dengan mudah. }\end{array}$ & & & & & \\
\hline 3 & Informasi dapat diakses dengan mudah. & & & & & \\
\hline 4 & $\begin{array}{l}\text { Menggunakan fitur Search / Pencarian dalam } \\
\text { melakukan pencarian data pasien dengan mudah. }\end{array}$ & & & & & \\
\hline 5 & $\begin{array}{l}\text { Program dilengkapi sistem pembetulan / } \\
\text { pengupdatean data pasien. }\end{array}$ & & & & & \\
\hline
\end{tabular}

\section{Hasil dan Pembahasan}

Dalam pengolahan hasil penelitian, penulis menetapkan beberapa tahapan penelitian untuk melakukan perhitungan menentukan seberapa manfaatkah penggunaan $e$-Puskesmas di Loket Pendaftaran Puskesmas Kecamatan Pademangan.

\subsection{Perhitungan Manual PIECES}

Berdasarkan hasil penilaian kuisioner terhadap pengguna aplikasi analisa dalam mengukur kualitas pelayanan terhadap kepuasan pengguna dengan menggunakan skala Likert untuk mengetahui 
tingkat kepuasan pengguna sistem $e$-Puskesmas sesuai dengan pilihan jawaban dan skornya, maka untuk mendapatkan rata-rata tingkat kepuasan dengan menggunakan minus :

$$
R K=\frac{J S K}{J K}
$$

Sumber : [11]

Keterangan :

RK = Rata-Rata Kepuasan

JSK = Jumlah Skor Kuesioner

$\mathrm{JK}=$ Jumlah Kuesioner

Sedangkan untuk menentukan tingkat kepuasan menggunakan model yang didefinisikan oleh Kaplan dan Norton [11] dengan tingkatan sebagai berikut :

\begin{tabular}{|c|c|}
\hline $1-1.79$ & $=$ Sangat Tidak Puas \\
\hline $1.8-2.59$ & $=$ Tidak Puas \\
\hline $2.6-3.39$ & $=$ Ragu-Ragu \\
\hline $3.4-4.91$ & $=$ Puas \\
\hline $4.92-5$ & $=$ Sangat Puas \\
\hline
\end{tabular}

Dengan penentuan tingkat kepuasan seperti diatas untuk tingkat kepuasan pengguna terhadap sistem analisa dalam mengukur kualitas pelayanan terhadap kepuasan konsumen. Adapun hasil pengolahan kuesioner dalam melihat tingkat kepuasan pelanggan adalah sebagai berikut:

1. Indikator Performance

Tabel 8. Hasil pengolahan kuesioner Indikator Performance

\begin{tabular}{ccccc}
\hline No & \multicolumn{4}{c}{ Indikator } \\
\cline { 2 - 5 } Responden & P1 & P2 & P3 & P4 \\
\hline 1 & 4 & 4 & 4 & 5 \\
2 & 5 & 4 & 4 & 4 \\
3 & 5 & 5 & 5 & 5 \\
4 & 4 & 4 & 3 & 4 \\
5 & 5 & 4 & 5 & 5 \\
6 & 4 & 4 & 4 & 4 \\
7 & 4 & 4 & 4 & 5 \\
8 & 4 & 4 & 4 & 4 \\
9 & 4 & 3 & 4 & 4 \\
10 & 5 & 4 & 4 & 5 \\
11 & 4 & 4 & 3 & 4 \\
12 & 4 & 4 & 4 & 4 \\
13 & 4 & 4 & 4 & 4 \\
14 & 3 & 3 & 3 & 3 \\
15 & 5 & 4 & 5 & 5 \\
16 & 5 & 4 & 4 & 4 \\
17 & 4 & 3 & 3 & 4 \\
Rata - Rata & 4.29 & 3.88 & 3.94 & 4.29 \\
\hline
\end{tabular}




$$
\begin{aligned}
\text { RK } & =\frac{4.29+3.88+3.94+4.29}{4} \\
\text { RK } & =\frac{16.41}{4} \\
\text { RK } & =4.10
\end{aligned}
$$

Berdasarkan hasil perhitungan jumlah rata- rata tingkat kepuasan diperoleh bernilai 4.10 pada domain Performance dan bila dipadukan dengan tingkat kepuasan menurut Kaplan dan Norton, maka dapat disimpulkan bahwa tingkat diperoleh rata-rata tingkat kepuasan berdasarkan domain adalah sebagai berikut:

Kepuasan pengguna terhadap e-Puskesmas termasuk dalam kategori PUAS. Sehingga hal ini menunjukkan indikasi yang positif yaitu pengguna sudah merasa puas dengan Performance dari $e$ Puskesmas.

\begin{tabular}{|c|c|c|c|c|}
\hline \multirow{2}{*}{$\begin{array}{c}\text { No } \\
\text { Responden }\end{array}$} & \multicolumn{4}{|c|}{ Indikator Information } \\
\hline & I1 & $\mathrm{I} 2$ & I3 & I4 \\
\hline 1 & 4 & 5 & 4 & 4 \\
\hline 2 & 4 & 4 & 5 & 4 \\
\hline 3 & 5 & 5 & 5 & 4 \\
\hline 4 & 3 & 4 & 4 & 4 \\
\hline 5 & 5 & 5 & 5 & 4 \\
\hline 6 & 4 & 4 & 4 & 4 \\
\hline 7 & 4 & 5 & 4 & 4 \\
\hline 8 & 4 & 4 & 4 & 4 \\
\hline 9 & 4 & 4 & 4 & 4 \\
\hline 10 & 4 & 5 & 5 & 5 \\
\hline 11 & 3 & 4 & 4 & 4 \\
\hline 12 & 4 & 4 & 4 & 4 \\
\hline 13 & 4 & 4 & 4 & 4 \\
\hline 14 & 3 & 3 & 3 & 3 \\
\hline 15 & 5 & 5 & 5 & 5 \\
\hline 16 & 4 & 4 & 5 & 5 \\
\hline 17 & 3 & 4 & 4 & 4 \\
\hline Rata - Rata & 3.94 & 4.29 & 4.29 & 4.12 \\
\hline RK & \multicolumn{4}{|c|}{$=\frac{3.94+4.29+4.29+4.12}{4}$} \\
\hline RK & \multicolumn{4}{|l|}{$=\frac{16.65}{4}$} \\
\hline RK & \multicolumn{4}{|l|}{$=4.16$} \\
\hline
\end{tabular}

\section{Indikator Information}

Tabel 9. Hasil pengolahan kuesioner Indikator Information

Berdasarkan hasil perhitungan jumlah rata- rata tingkat kepuasan diperoleh bernilai 4.16 pada domain Information dan bila dipadukan dengan tingkat kepuasan menurut Kaplan dan Norton, maka dapat disimpulkan bahwa tingkat diperoleh rata-rata tingkat kepuasan berdasarkan domain adalah sebagai berikut:

Kepuasan pengguna terhadap e-Puskesmas termasuk dalam kategori PUAS. Sehingga hal ini menunjukkan indikasi yang positif yaitu pengguna sudah merasa puas dengan Information dari $e$ Puskesmas. 


\section{Indikator Economy}

Tabel 10. Hasil pengolahan kuesioner Indikator Economy

\begin{tabular}{ccccc}
\hline No & \multicolumn{4}{c}{ Indikator Economy } \\
\cline { 2 - 5 } Responden & E1 & E2 & E3 & E4 \\
\hline 1 & 5 & 3 & 4 & 4 \\
2 & 4 & 5 & 4 & 4 \\
3 & 5 & 5 & 5 & 5 \\
4 & 4 & 5 & 3 & 3 \\
5 & 5 & 5 & 5 & 5 \\
6 & 4 & 4 & 4 & 4 \\
7 & 5 & 5 & 4 & 4 \\
8 & 4 & 5 & 4 & 4 \\
9 & 4 & 5 & 4 & 4 \\
10 & 5 & 5 & 4 & 4 \\
11 & 4 & 4 & 3 & 3 \\
12 & 4 & 4 & 4 & 4 \\
13 & 4 & 5 & 4 & 4 \\
14 & 3 & 4 & 3 & 3 \\
15 & 5 & 5 & 5 & 5 \\
16 & 4 & 5 & 4 & 4 \\
17 & 4 & 4 & 3 & 3 \\
Rata - Rata & 4.29 & 4.59 & 3.94 & 3.94 \\
\hline \multicolumn{5}{|c}{} \\
RK & $=4.29+4.59+4.94+3.94$ \\
RK & $=16.76$ & \multicolumn{4}{|c}{} \\
RK & $=4.19$ & \multicolumn{5}{|c}{} \\
\hline
\end{tabular}

Berdasarkan hasil perhitungan jumlah rata- rata tingkat kepuasan diperoleh bernilai 4.19 pada domain Economy dan bila dipadukan dengan tingkat kepuasan menurut Kaplan dan Norton, maka dapat disimpulkan bahwa tingkat diperoleh rata-rata tingkat kepuasan berdasarkan domain adalah sebagai berikut :

Kepuasan pengguna terhadap e-Puskesmas termasuk dalam kategori PUAS. Sehingga hal ini menunjukkan indikasi yang positif yaitu pengguna sudah merasa puas dengan Economy dari $e$ Puskesmas.

\section{Indikator Control}

Tabel 11. Hasil pengolahan kuesioner Indikator Control

\begin{tabular}{ccccc}
\hline No & \multicolumn{4}{c}{ Indikator Control } \\
\cline { 2 - 5 } Responden & C1 & C2 & C3 & C4 \\
\hline 1 & 4 & 4 & 5 & 4 \\
2 & 5 & 4 & 4 & 4 \\
3 & 5 & 4 & 5 & 5 \\
4 & 4 & 4 & 4 & 3 \\
5 & 5 & 4 & 5 & 5 \\
6 & 4 & 4 & 4 & 4 \\
7 & 4 & 4 & 5 & 4 \\
8 & 4 & 4 & 4 & 4 \\
9 & 4 & 4 & 4 & 4
\end{tabular}




\begin{tabular}{ccccc}
10 & 5 & 5 & 5 & 4 \\
11 & 4 & 4 & 4 & 3 \\
12 & 4 & 4 & 4 & 4 \\
13 & 4 & 4 & 4 & 4 \\
14 & 3 & 3 & 3 & 3 \\
15 & 5 & 5 & 5 & 5 \\
16 & 5 & 5 & 4 & 4 \\
17 & 4 & 4 & 4 & 3 \\
Rata - Rata & 4.29 & 4.12 & 4.29 & 3.94 \\
\hline
\end{tabular}

$$
\begin{aligned}
\text { RK } & =\frac{4.29+4.12+4.29+3.94}{4} \\
\text { RK } & =\frac{16.65}{4} \\
\text { RK } & =4.16
\end{aligned}
$$

Berdasarkan hasil perhitungan jumlah rata- rata tingkat kepuasan diperoleh bernilai 4.16 pada domain Control dan bila dipadukan dengan tingkat kepuasan menurut Kaplan dan Norton, maka dapat disimpulkan bahwa tingkat diperoleh rata-rata tingkat kepuasan berdasarkan domain adalah sebagai berikut :

Kepuasan pengguna terhadap e-Puskesmas termasuk dalam kategori PUAS. Sehingga hal ini menunjukkan indikasi yang positif yaitu pengguna sudah merasa puas dengan Control dari $e$-Puskesmas.

\begin{tabular}{|c|c|c|c|c|}
\hline \multirow{2}{*}{$\begin{array}{c}\text { No } \\
\text { Responden }\end{array}$} & \multicolumn{4}{|c|}{ Indikator Efficiency } \\
\hline & EF1 & EF2 & EF3 & EF4 \\
\hline 1 & 4 & 4 & 4 & 5 \\
\hline 2 & 5 & 4 & 4 & 4 \\
\hline 3 & 5 & 5 & 5 & 5 \\
\hline 4 & 4 & 4 & 3 & 4 \\
\hline 5 & 5 & 4 & 5 & 5 \\
\hline 6 & 4 & 4 & 4 & 4 \\
\hline 7 & 4 & 4 & 4 & 5 \\
\hline 8 & 4 & 4 & 4 & 4 \\
\hline 9 & 4 & 3 & 4 & 4 \\
\hline 10 & 5 & 4 & 4 & 5 \\
\hline 11 & 4 & 4 & 3 & 4 \\
\hline 12 & 4 & 4 & 4 & 4 \\
\hline 13 & 4 & 4 & 4 & 4 \\
\hline 14 & 3 & 3 & 3 & 3 \\
\hline 15 & 5 & 4 & 5 & 5 \\
\hline 16 & 5 & 4 & 4 & 4 \\
\hline 17 & 4 & 3 & 3 & 4 \\
\hline Rata - Rata & 4.29 & 3.88 & 3.94 & 4.29 \\
\hline RK & \multicolumn{4}{|c|}{$=\frac{4.29+3.88+3.94+4.29}{4}$} \\
\hline RK & \multicolumn{4}{|c|}{$=\frac{16.41}{4}$} \\
\hline RK & \multicolumn{4}{|l|}{$=4.10$} \\
\hline
\end{tabular}

5. Indikator Efficiency

Tabel 12. Hasil pengolahan kuesioner Indikator Efficiency 
Berdasarkan hasil perhitungan jumlah rata- rata tingkat kepuasan diperoleh bernilai 4.10 pada domain Efficiency dan bila dipadukan dengan tingkat kepuasan menurut Kaplan dan Norton, maka dapat disimpulkan bahwa tingkat diperoleh rata-rata tingkat kepuasan berdasarkan domain adalah sebagai berikut:

Kepuasan pengguna terhadap e-Puskesmas termasuk dalam kategori PUAS. Sehingga hal ini menunjukkan indikasi yang positif yaitu pengguna sudah merasa puas dengan Efficiency dari $e$ Puskesmas.

6. Indikator Service

Tabel 13. Hasil pengolahan kuesioner Indikator Service

\begin{tabular}{cccccc}
\hline No & \multicolumn{5}{c}{ Indikator Service } \\
\cline { 2 - 6 } Responden & S1 & S2 & S3 & S4 & S5 \\
\hline 1 & 4 & 4 & 5 & 4 & 4 \\
2 & 4 & 4 & 4 & 5 & 4 \\
3 & 5 & 5 & 5 & 5 & 5 \\
4 & 4 & 4 & 4 & 4 & 4 \\
5 & 4 & 4 & 5 & 4 & 4 \\
6 & 4 & 4 & 4 & 4 & 4 \\
7 & 4 & 4 & 5 & 4 & 4 \\
8 & 4 & 4 & 4 & 4 & 4 \\
9 & 3 & 3 & 4 & 3 & 3 \\
10 & 4 & 4 & 5 & 4 & 4 \\
11 & 4 & 4 & 4 & 4 & 4 \\
12 & 4 & 4 & 4 & 4 & 4 \\
13 & 4 & 4 & 4 & 5 & 4 \\
14 & 3 & 3 & 3 & 3 & 3 \\
15 & 4 & 4 & 5 & 4 & 4 \\
16 & 4 & 4 & 4 & 4 & 4 \\
17 & 3 & 3 & 4 & 3 & 3 \\
Rata - Rata & 3.88 & 3.88 & 4.29 & 4.00 & 3.88 \\
\hline RK = $3.88+3.88+4.29+4.00+3.88$ \\
RK = 19.94 \\
RK = 3.99
\end{tabular}

Berdasarkan hasil perhitungan jumlah rata- rata tingkat kepuasan diperoleh bernilai 3.99 pada domain Service dan bila dipadukan dengan tingkat kepuasan menurut Kaplan dan Norton, maka dapat disimpulkan bahwa tingkat diperoleh rata-rata tingkat kepuasan berdasarkan domain adalah sebagai berikut :

Kepuasan pengguna terhadap e-Puskesmas termasuk dalam kategori PUAS. Sehingga hal ini menunjukkan indikasi yang positif yaitu pengguna sudah merasa puas dengan Service dari $e$-Puskesmas.

Tabel 14. Hasil Rekapitulasi Indikator

\begin{tabular}{lc}
\hline \multicolumn{1}{c}{ Indikator } & Nilai \\
\hline Performance & 4.10 \\
Information & 4.16 \\
Economy & 4.19 \\
Control & 4.16 \\
Efficiency & 4.10 \\
Service & 3.99 \\
\multicolumn{1}{c}{ Jumlah Rata - Rata } & $\mathbf{4 . 1 2}$ \\
\hline
\end{tabular}


Berdasarkan hasil perhintungan pada setiap indikator Performance, Information, Economy, Control, Efficiency, Service mendapatkan jumlah rata-rata tingkat kepuasan diperoleh nilai 4.12, maka dapat disimpulkan bahwa tingkat kepuasan pengguna terhadap $e$-Puskesmas termasuk dalam kategori PUAS. Sehingga hal ini menunjukkan indikasi yang positif yaitu pengguna sudah merasa puas dengan pemanfaatan $e$-Puskesmas di loket pendaftaran.

\section{Kesimpulan}

hasil dari penelitian yang dilakukan dengan menggunakan metode PIECES dan dari hasil kuesioner menyimpulkan bahwa :

1. Dengan menggunakan analisis metode PIECES dapat memberikan gambaran pada Puskesmas Kecamatan Pademangan bahwa $e$-Puskesmas sangat bermanfaat dan berperan penting di Loket Pendaftaran yang digunakan oleh petugas dalam memberikan pelayanan terhadap pasien.

2. Dengan menggunakan analisa metode PIECES dapat diketahui bagaimanakah Kepuasan petugas dalam menggunakan e-Puskesmas di Loket Pendaftaran berdasarkan indicator Performance, Information, Economy, Control, Efficiency, dan Service.

\section{Referensi}

[1] hendra nusa Putra, "Analisis Pelaksanaan Sistem E-Puskesmas Dengan Menggunakan Metode Pieces Di Puskesmas Pemancungan Padang Tahun 2018," Ensiklopedia, vol. 1, no. 1, pp. 244 247, 2018.

[2] L. Devid, D. Mardiawati, and D. Sari, "ANALISIS PEMANFAATAN E-PUSKESMAS DENGAN METODE PERFOMANCE, INFORMATION, EKONOMI, CONTROL, DAN EFISIENSI, SERVICE (PIECES) DI PUSKESMAS KOTA PADANG," Ensiklopedia, vol. 1, no. 1, pp. 17-26, 2018.

[3] Z. Arifin, "Kriteria Instrumen dalam suatu Penelitian," J. Theorems (the Orig. Res. Math., vol. 2, no. 1, pp. 28-36, 2017.

[4] A. Supriyatna, "Analisis Dan Evaluasi Kepuasan Pengguna Sistem Informasi Perpustakaan Dengan Menggunakan Pieces Framework," None, vol. 11, no. 1, pp. 43-52, 2015.

[5] R. D. Kristy and W. A. Kusuma, "MALANG," Anal. TINGKAT KEPUASAN DAN TINGKAT KEPENTINGAN PENERAPAN Sist. Inf. Univ. MUHAMMADIYAH MALANG Rellanti, vol. 2, pp. 17-24, 2018.

[6] N. Agustina, "Evaluasi Penggunaan Sistem Informasi ERP Dengan Metode Pieces Framework," J. Inform., vol. 5, no. 2, pp. 278-286, 2018.

[7] E. Junaidi, S. Hadisaputra, and W. S. Al Idrus, "KAJIAN PELAKSANAAN PRAKTIKUM KIMIA DI SEKOLAH MENENGAH ATAS DI KABUPATEN LOMBOK BARAT INDONESIA," J. Pijar MIPA, vol. 1, no. 1, pp. 45-50, 2018.

[8] R. Tullah and M. I. Hanafri, "Evaluasi Penerapan Sistem Informasi Pada Politeknik LP3I Jakarta Dengan Metode Pieces," J. Sisfotek Glob., vol. 4, no. 1, pp. 22-28, 2014.

[9] A. R. Dewi, "Analisis Sistem Informasi Pengolahan Data Nilai Mahasiswa Menggunakan PIECES pada Prodi Sistem Informasi,” Query, vol. 5341, no. October, pp. 37-46, 2018.

[10] A. Wedianto, H. L. Sari, and Y. S. H, "Analisa Perbandingan Metode Filter Gaussian, Mean Dan Median Terhadap Reduksi Noise," J. Media Infotama, vol. 12, no. 1, pp. 21-30, 2016.

[11] Y. Asbar and M. A. Saptari, "Analisa Dalam Mengukur Kualitas Pelayanan Terhadap Kepuasan Konsumen Menggunakan Metode PIECES," J. Visioner Strateg., vol. 6, no. 2, pp. 39-47, 2017.

[12] R. Alfian and P. M. A. Putra, "Jurnal Ilmiah Ibnu Sina, 2 (2), 176-183 Riza Alfian," J. Ilm. Ibnu Sina, vol. 2, no. September, pp. 176-183, 2017. 